This work has been supported by a research grant from the U.S. Public Health Service, C4682.

${ }^{1}$ Lindegren, C. C., and Lindegren, G., Genetica, 26, 430 (1953).

${ }^{2}$ Palleroni, N. J., and Lindegren, C. C., J. Bacteriol, , 65, 122 (1953).

${ }^{3}$ Lindegren, C. C., Pittman, D., and Ranganathan, B., Intern. Geretics, Japan Cy tologia Supp., 42 (1957).

4 Pittman, D., U.S. Atomic Energy Comm. Prog. Rep. (1958).

'Lindegren, C. C., and Pittman, D., Genetica, 30, 169 (1959).

- Pittman, D., and Lindegren, C. C., Genetics, 44, 389 (1957).

'Pittman, D., Ranganathan, B., and Lindegren, C. C., U.S. Atomic Energy Comm. Prog. Rep. (1958).

s Lindegren, C. C., and Pittman, D., J. Gen. Micro., 9, 494 (1953).

- Lindegren, C. C., C.R. Lab. Carlsberg, Ser. Physiol., 26, 253 (1956).

${ }^{10}$ Lindegren, C. C., and Pittman, D. D., Nature, 182, 271 (1958).

11 Newcombe, H. B., Nature, 164, 150 (1949).
${ }^{22}$ Lindegren, C. C., Bacteriol. Proc., 76 (1960).

1s Lindegren, C. C., J. Theor. Biol. (in the press).

14 Pontecorvo, G., Trends in Genetic Analysis, 135 (Columbia Univ. Press, New York, 1938).

${ }^{16}$ Steffensen, D., Proc. O.S. Nat. Acad. Sci., 41, 155 (1955),

${ }^{16}$ Hoagland, M. B., Brookhaven Symp. Biol., Structure and Function of Genetic Elements, No. 12, 40 (1959).

12 Pittman, D., Trans. III, Acad. Sci. (1961).

${ }^{18}$ Pittman, D., Bacterial Proc. (1961).

19 Oparin, A., The Origin of Life on the Earth, third ed., 495 (Academic Press, Inc., New York, 1957).

20 Pauling, L., J. Amer. Chem. Soc., 62, 2643 (1940).

21 Jollos, V., Archiv fur Protistenkunde, 83, 197 (1934).

${ }^{22}$ Watson, J. D., and Crick, F. H. C., Nature, 171, 964 (1953).

23 Lindegren, C. C., Nature, 176, 1244 (1955).

24 Iindegren, C. C., N.Y. Acad. Sci., 69, 338 (1957).

\title{
OBITUARIES
}

\section{Prof. Maud Menten}

Maud Menten, experimental pathologist, died on July 20,1960, at the age of eighty-one in Leamington, Ontario. She was born in Lambton County, Canada, in 1879 and received the B.A. degree at the University of Toronto in 1904, the bachelor of medicine degree in 1907 and her M.D. in 1911. In 1916 she obtained a Ph.D. degree in biochemistry at the University of Chicago, where she studied with A. P. Mathews. Between 1904 and 1905 she was a demonstrator in. physiology in the laboratories of A. B. Macallum. During 1907-8 she was a Research Fellow at the Rockefeller Institute for Medical Research, and, together with Simon Flexner and J. W. Jobling, was author of the first monograph of the Institute, a work on radiobromide and cancer. During 1910-12 and 1913-14 she was a Research Fellow at Western Re. serve University in the sphere of Dr. George Crile. In 1913 she worked with L. Michaelis in Berlin, and this collaboration resulted in the famous paper on chemical kinetics which appeared in 1913 in the Biochemische Zeitschrift. In 1915-16 she did research in cancer at the Barnard Skin and Cancer Hospital in St. Louis, Missouri. In 1916 she joined the School of Medicine of the University of Pittsburgh, Pennsylvania, where she remained until her retirement in 1950. In Pittsburgh she was pathologist to the Children's Hospital of Pittsburgh from 1926 until 1950, and was a full-time teacher in the Department of Pathology of the Medical School; she rose to become a full professor of pathology. On retirement, she continued to do research work on cancer at the Medical Research Institute of British Columbia, until ill-health forced complete cessation of scientific activity in 1955 .

Maud Menten was an avid research worker all her life. In Pittsburgh, despite full schedules as a hospital pathologist and teacher of pathology, she continued to make noteworthy contributions to scientific literature.

She was a versatile scientist, as becomes a pathologist. She will be best remembered at present for four pieces of work. Her work on enzyme kinetics with Michaelis in 1913 resulted in the MichaelisMenten constant. In 1924, together with Helen Manning, she discovered the hyperglycæmic effects of salmonella toxins. In 1944, together with Andersch and Wilson, she determined the sedimentation constants and electrophoretic mobilities of adult and foetal carboxylhæmoglobin; this has been stated to be the first use of electrophoretic mobility to de- termine differences in human hæmoglobin, antedating Linus Pauling. In 1944, together with Junge and Green, she developed an azo-dye coupling reaction for the demonstration of alkaline phosphatase in the kidney. This piece of work was called enthusiastically "a stroke of genius" by A. G. Pearse in the first edition of his book on Histochemistry because it opened up a field of enzyme histochemistry. Other research papers encompassed work on potassium in cells (with A. B. Macallum), radiobromide and cancer (with Simon Flexner and J. W. Jobling), oxidases, vitamin C (with C. G. King and O. Bessey), streptococcal toxins, histochemistry of glycogen, and nucleic acids in bone marrow. Other papers were published in the fields of physiology, chemotherapy, hæmatology and pathology.

Dr. Menten was a member of numerous scientific societies. Aside from science, she was a student of languages, music and art. She was a fine painter, and several of her canvases were hung in art exhibitions.

Maud Menten was untiring in her efforts on behalf of sick children. She was an inspiring teacher who stimulated medical students, resident physicians and research associates to their best efforts. She will long be remembered by her associates for her keen mind, for a certain dignity of manzer, for unobtrusive modesty, for her wit, and above all for her enthusiasm for research.

\section{Aaron H. Stock} Anna-Mary Carpenter

\section{Prof. G. Bonnier}

Prof. Gert Bonnier died on January 11 in Stockholm, where he had held the chair of genetics from 1936 until 1958. Even after his retirement he continued his experimental work until a fow days before his death. He belonged to the generation of geneticists who, under the influence of the Morgan school, started to anslyse the mechanism of heredity by means of experiments with Drosophila. One of his earliest papers, published before he had obtained his doctorate, is a thorough and ingenious study of secondary non-disjunction, which may gain renewed importance now that non-disjunction in man has proved to be a source of profound pathological disturbances. Crossing-over in triploids and attached $X$-chromosomes, chromatid interference, gynandromorphism and mosaicism were among the problems that interested him most. In 1947 , together with $B$. and M. Rasmuson, he published a paper on "Gene Divisibility", which at the time of its appearance 